\title{
The Effect of Academic Self Efficacy on Achievement Motivation-Mediated Resilience
}

\author{
Bhatara Dharma Wijaya ${ }^{1}$, Baidi Bukhori ${ }^{2}$, Wening Wihartati ${ }^{3}$, Hartanto ${ }^{4}$ \\ UIN Walisongo, Semarang ${ }^{1,2,3}$, Universitas Widya Dharma Klaten ${ }^{4}$ \\ \{bhatara.wijaya@gmail.com¹, baidi_bukhori@walisongo.ac.id²,wening_wihartati@walisongo.ac.id², \\ tanto_psychology@unwidha.id ${ }^{4}$ \}
}

\begin{abstract}
This study aims to test the effect of self-efficacy on resilience with achievement motivation as a mediator variable empirically. This study's subjects were 211 students of the State Islamic University of Walisongo Semarang, who were santri. The sampling technique used was proportional stratified random sampling. The data were collected using a self-efficacy scale, a scale of achievement motivation, and a resilience scale. Self-efficacy was shown to have a significant effect both directly (beta $=0.413 ; \mathrm{p}<0.01$ ) and through achievement motivation ( $b e t a=0.297 ; \mathrm{p}<0.01$ ) on resilience. The total effect of self-efficacy and achievement motivation on resilience was $0.710(p<0.01)$. These results can be a suggestion or reference regarding the dynamics of students' resilience with the status of santri, the importance of increasing selfefficacy, and always maintaining and developing the santri' achievement motivation.
\end{abstract}

Keywords: Academic Self Efficacy; Achievement Motivation; Resilience

\section{Introduction}

The boarding school or dormitory as a place to live is also a place for the development of students' self-actualization with the status of santri. The dense activities of students living in Islamic boarding schools or dormitories make them have to work extra hard in carrying out their responsibilities. As a result, there will be conflicts between roles that intersect with each other [1]. Therefore, students who live in Islamic boarding schools or dormitories have crucial problems related to fulfilling campus and dormitory academic obligations and must have high independence in doing assignments and must solve solutions related to problems that arise both on campus and in a dormitory or boarding school.

Students who have many roles must be able to survive with the busy activities. The primary key for a person to survive and adapt is resilience, which is a person's ability to make them survive and be strong in facing many problems [2]. Resilience can also define the individual's ability to rise when facing unpleasant events, with emotional stability and physical and psychological functions [3]. Resilience is needed so that each individual can try to deal with the stress that arises, feel happy, face problems, and adjust to various situations [4]. According to Asy'ari, Bukhori, and Ma'shumah, individuals with high resilience can see 
positively towards negative pressures and are able to adapt [5]. They can also turn unpleasant things into pleasant or beneficial things [6].

According to Connor and Davidson, there are five aspects of resilience, namely (1) personal competence: leads to individual resilience to achieve goals despite facing failure, (2) self-confidence in dealing with pressures, (3) the ability to accept change positively or the ability to adapt to change, (4) self-control, control over the problems at hand, and (5) spiritual influence, faith in God, and destiny [7]. All of these series of aspects are internal factors related to how much self-confidence.

Furthermore, students who live in dormitories or Islamic boarding school have high resilience, so they must have high self-efficacy. Self-efficacy means a person's belief in their ability to perform tasks [8]. A person's self-efficacy affects behavior, motivation, thought patterns, and emotional reactions in various situations [9]. Someone who has high selfefficacy tends not to easily give up in facing situations [10], avoid undesirable actions [11], and avoid anxiety and depression [12]. Hence, self-efficacy can affect the resilience of students living in an Islamic boarding school.

According to Rizvi, Johana, and Helly, there are three aspects of self-efficacy, namely (1) the expectation of results, related to expectations of possible results, (2) the hope of efficacy, related to a person's belief that he or she can take the necessary actions, so that achieve results, and (3) the value of results related to the mean value of individual gains [13]. Hence, according to Bandura, there are three aspects: magnitude, generality, and strength [14].

Meanwhile, according to Lauster, self-efficacy consists of five aspects. These aspects of efficacy are: (1) Self-confidence is one's abilities in the form of a positive attitude and understands and truthfully about what is doing, (2) Optimistic about yourself for a positive attitude by always having a good view in dealing with everything about yourself, expectations, and abilities, (3) Objective, namely individuals who are confident in viewing tasks or problems following the moral truth, not according to personal subjectivity, (4) Taking responsibility, namely the individual's willingness to bear something that has become the consequence, (5) Rational and realistic, namely the individual analysis of a problem, a thing, an event with a viewpoint of thought that is acceptable to reason and following reality [15].

Apart from self-efficacy, achievement motivation is vital for everyone [16], especially those who have a dual role, namely playing as a student and a student. Achievement motivation is a crucial characteristic of behavior that impacts individuals in dealing with their tasks [17]. A person with high achievement motivation will have a high n-ach orientation and will support the realization of resilience [18]. Research by Mardiana [19] and Ramadhani et.al. [20] showed that there is a relationship between achievement motivation and resilience.

In addition to achievement motivation influencing resilience, achievement motivation also influences by self-confidence or self-efficacy [21]. Someone who has high confidence and knows their potential will have the motivation to achieve high as well. Amir's research shows that achievement motivation influences one's potential and correct beliefs about oneself. The influence of academic self-efficacy on achievement motivation is stimulation to arrive at expectations, achievements, aspirations, or success [22]. According to Maslow's theory of the hierarchy of needs, achievement motivation plays a vital role in maintaining a rhythm in order to be able to master tasks and survive in the face of life's challenges [23]. It is under the word of Allah Surah Al-Insyirah verse 7, which reads, "So when you have finished (from an affair), keep working hard (for other matters)."

According to McClelland, Rindlisbacher, \& Brown, achievement motivation is an attempt to achieve success or success in competition with a standard or basis that can be in the form of other people's achievements [24]. A similar opinion was also conveyed by Singh that 
achievement motivation is the spirit to do well or strive to achieve success, as evidenced by tenacity and effort to face difficulties [25].

Aspects of achievement motivation according to Hersey, Blancard, \& Johnson are divided into four, namely (1) Feeling more like achievement than wages, (2) In working they will show themselves according to what they are, (3) Feel like a failure when their duties' success depends a lot on other people, and (4) in their position as managers, they are often less skilled and impatient in taking an interpersonal approach [26]. Meanwhile, according to McClelland et al., achievement motivation consists of four aspects, namely (1) being responsible, (2) requiring feedback, (3) being innovative, and (4) being successful at work [24].

The description above concluded that resilience is influenced by many factors, either directly or indirectly, through achievement motivation. Individual who obtains high resilience, each individual must be able to understand the factors that influence it. It is essential because this understanding will lead to defining, self-mapping, improving, and developing selfunderstanding that is owned by individuals.

\section{Method}

This research is quantitative research with one independent variable, one mediator variable, and one dependent variable. The independent variable is academic self-efficacy; the mediating variable is achievement motivation, while the dependent variable is resilience. This study's population was 498 students who were also santri who spread across four student Islamic boarding school or dormitories, namely Ma'had Ali Al-Jami'ah UIN Walisongo, Bina Insani, Dar Al-Qalam, and Ma'rufiyah. This study's sample was with the proportionate stratified random sampling technique based on the proportion of the number of samples and specific criteria [27]. The criteria for the subjects to be sampled were students in semesters two to six meters which were willing to fill out questionnaires and research questionnaires. The number of samples is 211 students who are santri.

The instrument used for data collection consisted of three scales: academic self-efficacy, resilience scale, and achievement motivation scale. The academic self-efficacy scale consists of 30 items, which divides into five categorical aspects, namely, self-belief in one's abilities, self-optimism for the positive, objective, responsible, and rational and realistic attitudes [15], with a reliability coefficient of 0.891 . The resilience scale consists of 41 items that divide into five aspects: personal competence, self-confidence, the ability to accept change positively, self-control, and the influence of spirituality [7] reliability coefficient of 0.928 . Achievement motivation scale consists of 27 items divide into four aspects, namely, responsible, requires bait, innovative, successful at work [24], with a reliability coefficient of 0.909 . Mediation analysis carries out with the help of JASP software [28]. The purpose of using this model is to determine whether motivation becomes a mediator between academic self-efficacy and resilience.

\section{Results and Discussions}

\subsection{Results}




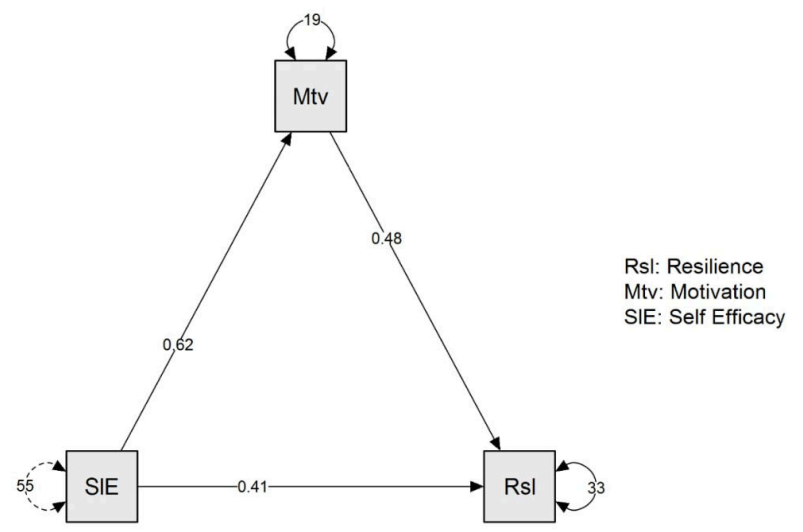

Fig 1. Dynamics of Influence between Variables

Table 1. Direct effect estimates

Direct effects

$95 \%$ Confidence Interval

\begin{tabular}{lrrrccr}
\hline & Estimate & Std. Error & z-value & p & Lower & \multicolumn{1}{c}{ Upper } \\
\hline EFFICACY $\rightarrow$ RESILIENCE & 0.413 & 0.078 & 5.317 & $<.001$ & 0.261 & 0.565
\end{tabular}

Table of the direct effect of efficacy on resilience. Efficacy has a significant effect on resilience, with the estimated value of the regression coefficient (intercept) of 0.413 ( $p$ $<0.001$ ) and the critical ratio (C.R) or also known as the $z$ value ( $\mathrm{z}$-value) is 5,317 obtained from dividing the estimated parameter by standard error. The value limit is a value above 1.96 . The standard error value is 0.078 , which is the error value of the estimated coefficient, which is the mean value of the distance between the data points (observed data) to the regression line. This error can involve many things, including sampling errors and systematic errors. The small value is the answer. According to Baron and Kenny, the predictor's direct influence on the mediator and the predictor to the criteria must be significant because it is essential to support the mediator analysis [29].

Table 2. Indirect effect estimates

\begin{tabular}{|c|c|c|c|c|c|c|}
\hline & \multirow[b]{2}{*}{ Estimate } & \multirow[b]{2}{*}{$\begin{array}{c}\text { Std. } \\
\text { Error }\end{array}$} & \multirow[b]{2}{*}{$\begin{array}{c}\mathbf{z}- \\
\text { value }\end{array}$} & \multirow[b]{2}{*}{$\mathbf{p}$} & \multicolumn{2}{|c|}{$\begin{array}{c}95 \% \text { Confidence } \\
\text { Interval }\end{array}$} \\
\hline & & & & & Lower & Upper \\
\hline$\overline{\text { EFFICACY } \rightarrow \text { MOTIVATION } \rightarrow \text { RESILIENCE }}$ & 0.297 & 0.060 & 4.987 & $<.001$ & 0.180 & 0.414 \\
\hline
\end{tabular}

It was found that motivation mediated the effect of efficacy on resilience significantly with a beta value $=0.297(\mathrm{p}<0.01)$, and a value of C.R $($ critical ratio $)=4.987$ (estimate/standard error). 
Table 3. Total effect estimates

Total effects

\begin{tabular}{lrrrrrrr}
\hline & & & & & \multicolumn{2}{c}{$\mathbf{9 5 \%}$ Confidence Interval } \\
\cline { 4 - 7 } & Estimate & Std. Error & z-value & p & Lower & \multicolumn{1}{c}{ Upper } \\
\hline EFFICACY $\rightarrow$ RESILIENCE & 0.710 & 0.057 & 12.488 & $<.001$ & 0.599 & 0.822 \\
\hline
\end{tabular}

The total effect of the regression coefficient is 0.710 . This total effect expects to be significant because if this total effect is not significant, then the indirect effect is also insignificant $\left(c=c^{1}+a * b\right)$. From the analysis, it found that both direct and indirect effects proved significant, indicating partial mediation.

The analysis showed that the total effect of self-efficacy on resilience was 0.7102 ( $p$ $<0.01$ ). The direct effect of self-efficacy on resilience was 0.4130 , indicating a significant result $(p<0.01)$. The results also showed a mediating effect of the motivation of 0.2973 . It means that there is an indirect effect of self-efficacy on resilience, namely through motivation.

\subsection{Discussion}

Based on hypothesis testing, academic self-efficacy and achievement motivation have positive results both simultaneously and partially on students' resilience. It provides an understanding that the higher the academic self-efficacy and achievement motivation, the higher the resilience, and vice versa. Santrock explained that a person's level of self-efficacy will impact strong beliefs so that they have an achievement boost (n-ach) following the desired goals [30]. Following the study of Amir, which showed the effect of self-efficacy on achievement motivation. The higher the self-efficacy, the higher the achievement motivation [22].

The same opinion was also conveyed by Zimmerman \& Schunk that an individual's selfefficacy will give a strong belief effect and have the drive to achieve the expected achievement [30]. In line with Zimmerman's opinion, according to Ormrod, if someone has high self-efficacy, they will have the belief to direct behavior towards success so that with academic self-efficacy, they have beliefs that lead to behavior to complete all activities for which they are responsible [21]. Students who are santri with high achievement motivation indicate that they have high self-efficacy. Bandura stated that high self-efficacy will have consistency in the activities, goals, and efforts undertaken [21]. According to Alwisol, if a person has high self-efficacy, he/she will be competent and make someone grow, cook, and be ready to face challenges [23]. In line with Feist, Gregory, \& Tomi-Ann, a person with high self-efficacy will have the belief that they can take an action that produces the desired behavior in particular situations [31].

The accumulated behavioral orientation then forms resistance and positive adaptation patterns. From this, according to Mardiana's research that achievement motivation is related to resilience [19]. Achievement motivation is a crucial characteristic of behavior that has an essential impact on individuals' endurance in facing their tasks [17]. According to Desmita, someone with high achievement motivation will have a high $n$-ach orientation and will support the realization of resilience [18]. Following the results of Ramadhani, there is a relationship 
between achievement motivation and resilience [20]. The series pattern illustrates that achievement motivation can mediate between academic self-efficacy and resilience.

Besides, resilience is influenced indirectly through achievement motivation. Resilience can also be influenced directly by academic self-efficacy. Based on Arasibenginiate's research, there is an effect of self-efficacy on resilience [32]. According to Ormrod, someone with high self-efficacy will be persistent and not give up on facing challenges [21]. Also, someone will feel competent and make someone able to grow, cook, and be ready to face their problems [23]. Therefore, in daily activities with a double burden in studying on campus and activities at Islamic boarding schools, students with the status of santri will be competent with the tasks they have to go hand in hand. Other studies reveal that the higher the self-efficacy, the higher the resilience [33]. Students who have the status of santri who have high resilience will feel confident in facing problems because they are optimistic about solving them. According to Roellyana \& Ratih, that optimism has a significant effect on student resilience. In other words, optimism plays a vital role in building resilience. The more optimistic the individual allows increasing his resilience [34].

The result showed that the total effect of academic self-efficacy through achievement motivation on resilience was $71 \%$, while the remaining $29 \%$ influenced by other variables, such as spirituality [2], social support [35], religiosity [36], self-concept [37]. In other words, someone who has a high degree of spirituality, religiosity, self-concept, and adjustment, the higher the degree of resilience, and vice versa. This study concluded that academic selfefficacy and achievement motivation could make a positive contribution to increasing resilience. Individuals with a higher degree of achievement motivation can display persistent behavior to make adjustments and have high optimism. Besides that, they have the substantial capacity to withstand the problems and tasks that are their responsibility in campus and boarding schools or dormitories.

\section{Conclusion}

This study concludes that there is a positive influence on academic self-efficacy and achievement motivation of students who are santri either simultaneously or partially. It provides an understanding that achievement motivation can mediate between academic selfefficacy and resilience. Also, the higher the academic self-efficacy and achievement motivation, the higher the resilience of students with the status of santri.

\section{References}

[1] M. A. Aulia and D. Rusmawati, "Hubungan antara konflik peran ganda dengan motivasi berprestasi pada mahasiswi yang sudah berkeluarga di Jombang," Empati, vol. 9, no. 1, pp. 9-14, 2020.

[2] B. Bukhori, Z. Hassan, I. Hadjar, and R. Hidayah, "The effect of sprituality and social support from the family toward final semester university students' resilience," Man India, vol. 97, no. 19, pp. 313-321, 2017.

[3] Y. Kurniawan and N. Noviza, "Peningkatan Resiliensi pada Penyintas Kekerasan terhadap Perempuan Berbasis Terapi Kelompok Pendukung," Psikohumaniora: Jurnal Penelitian Psikologi, vol. 2, no. 2, May 2018, doi: 10.21580/pjpp.v2i2.1968.

[4] D. T. Indirasari, D. E. Purba, and R. Anindita, "Future time perspective and turnover 
intention: The mediating role of resilience," Psikohumaniora: Jurnal Penelitian Psikologi, vol. 4, no. 1, Apr. 2019, doi: 10.21580/pjpp.v4i1.3120.

[5] M. U. Asy'ari, B. Bukhori, and L. A. Ma'shumah, "The effect of quality of school life and resilience on academic stress in students," J. Psikol. Integr., vol. 7, no. 2, pp. 185198, 2019, doi: doi.org/10.14421/jpsi.v7i2.1765.

[6] I. Izzaturrohmah and N. M. Khaerani, "Peningkatan resiliensi perempuan korban pelecehan seksual melalui pelatihan regulasi emosi," Psikohumaniora: Jurnal Penelitian Psikologi, vol. 3, no. 1, Aug. 2018, doi: 10.21580/pjpp.v3i1.2527.

[7] K. M. Connor and J. R. T. Davidson, "Development of a new resilience scale: The Connor-Davidson resilience scale (CD-RISC)," Depress. Anxiety, vol. 18, no. 2, pp. 76-82, 2003, doi: doi.org/10.1002/da.10113.

[8] D. D. B. Situmorang, M. E. Wibowo, and M. Mulawarman, "Konseling Kelompok Active Music Therapy Berbasis Cognitive Behavior Therapy (CBT) untuk Meningkatkan Self-Efficacy Mahasiswa Millennials," Psikohumaniora: Jurnal Penelitian Psikologi, vol 3, No 1 (2018)DO - 10.21580/pjpp.v3i1.2508, Aug. 2018, doi: 10.21580/pjpp.v3i1.2508.

[9] R. A'yun Qurrota and N. Hartini, "Can cognitive behavioral-therapy increase the quality of life and self-efficacy in rheumatoid arthritis patients?," Psikohumaniora: Jurnal Penelitian Psikologi, vol. 4, no. 2, Oct. 2019, doi: doi.org/10.21580/pjpp.v4i2.4184.

[10] D. P. Schultz and Sydney Ellen Schultz, Teori Kepribadian. Jakarta: EGC, 2016.

[11] B. Bukhori and Darmu'in, "Plagiarism, Self-Efficacy, and Academic Procrastination on University Students," Psympathic J. Ilm. Psikol., vol. 6, no. 2, pp. 201-212, 2019, doi: 10.15575/psy.v6i2.6211.

[12] A. Iskayanti and N. Hartini, "Self-efficacy parenting and nursing stress: Study on mother from spectrum autism children," Psikohumaniora: Jurnal Penelitian Psikologi, vol. 4, no. 1, Apr. 2019, doi: 10.21580/pjpp.v4i1.3298.

[13] A. Rizvi, J. E. Prawitasari, and H. P. Soetjipto, "Pusat kendali dan efikasi-diri sebagai prediktor terhadap prokrastinasi akademik mahasiswa," Psikologika J. Pemikir. Dan Penelit. Psikol., vol. 2, no. 3, pp. 51-66, 1997, doi: 10.20885/psikologika.vol2.iss3.art6.

[14] A. Bandura, Self-efficacy: the exercise of control. New York: Freeman, 1997.

[15] P. Lauster, Tes Kepribadian. Jakarta: PT. Gramedia Pustaka Utama., 1988.

[16] B. Bukhori, H. Said, T. Wijaya, and F. M. Nor, "The Effect of Smartphone Addiction, Achievement Motivation, and Textbook Reading Intensity on Students' Academic Achievement," Int. J. Interact. Mob. Technol., vol. 13, no. 9, pp. 66-80, 2019.

[17] R. Slavin, Psikologi pendidikan (teori dan praktik). Jakarta: PT. Indeks, 2011.

[18] Desmita, Psikologi perkembangan peserta didik. Bandung: PT. Remaja Rosdakarya, 2016.

[19] T. Mardiana, D. Chairilsyah, and D. Risma, "Hubungan antara self resiliensi dengan motivasi berprestasi mahasiswa PG Paud angkatan 2015 fakultas keguruan dan ilmu pendidikan universitas Riau," J. Online Mhs. Bid. Kegur. dan Ilmu Pendidik., vol. 4, no. 2, pp. 1-13, 2017.

[20] F. Ramadhani, "Hubungan antara resiliensi dan kepercayaan diri dengan motivasi berprestasi pada penyandang cacat tubuh di balai besar rehabilitasi sosial bina daksa prof. dr. soeharso Surakarta," J. Ilm. Psikol. Candrajiwa, vol. 3, no. 2, pp. 97-107, 2014.

[21] J. E. Ormrod, Psikologi pendidikan (membantu siswa tumbuh dan berkembang). 
Jakarta: PT. Erlangga, 2008.

[22] H. Amir, "Korelasi pengaruh faktor efikasi diri dan manajemen diri terhadap motivasi berprestasi pada mahasiswa pendidikan kimia Unversitas Bengkulu," Manajer Pendidik., vol. 10, no. 4, pp. 336-342, 2016.

[23] Alwisol, Psikologi Kepribadian. Malang: UMM Press, 2014.

[24] D. C. McClelland, V. Patel, D. Stier, and D. Brown, "The relationship of affiliative arousal to dopamine release," Motiv. Emot., vol. 11, no. 1, pp. 51-66, 1987, doi: 10.1007/BF00992213.

[25] K. Singh, "Study of achievement motivation in relation to academic achievement of students," Int. J. Educ. Plan. Adm., vol. 1, no. 2, pp. 161-171, 2011, doi: 10.12691/education-4-15-3.

[26] P. Hersey, K. H. Blanchard, and D. E. Johnson, Management of organizational behavior leading human resource, 8th ed. Upper Saddles River, New Jersey: Prentice Hall., 1996.

[27] Sugiyono, Metode Penelitian Kuantitatif, Kualitatif dan $R \& D$. Bandung: Alfabeta, 2018.

[28] J. Team, “JASP (Version 0.13.1).” https://jasp-stats.org/, 2020.

[29] R. Baron and D. Kenny, "The moderator-mediator variable distinction in social psychological research: Conceptual, strategic, and statistical considerations," J. Pers. Soc. Psychol., vol. 51, pp. 1173-1182, Jan. 1986, doi: 10.1037//0022-3514.51.6.1173.

[30] J. Santrock, Educational Psychology. New York: McGraw-Hill, 2006.

[31] J. Feist, G. J., and T.-A. Roberts, Teori Kepribadian (Translator: R.A. Hadwitia Dewi Pertiwi). Jakarta: Salemba Humanika, 2017.

[32] V. A. Arasibenginiate, "Pengaruh perceived stress, efikasi diri, gratitude, dukungan sosial, dan faktor demografi terhadap resiliensi penyandang autoimun," Fakultas Psikologi UIN Syarif Hidayatullah Jakarta.

[33] I. WAHYUNI, "Pengaruh efikasi diri terhadap resiliensi diri pada guru sekolah dasar swasta di Jakarta Timur," Universitas Negeri Jakarta, 2018.

[34] S. Roellyana and R. A. Listiyandini, "Peranan optimisme terhadap resiliensi pada mahasiswa tingkat akhir yang mengerjakan skripsi," Pros. Konf. Nas. Peneliti Muda Psikol. Indones., vol. 1, no. 1, pp. 29-37, 2016.

[35] A. C. Mufidah, "Hubungan antara dukungan sosial terhadap resiliensi pada mahasiswa bidikmisi dengan mediasi efikasi diri," J. Sains Psikol., vol. 6, no. 2, pp. 68-74, 2017, doi: 10.17977/um023v6i12017p068.

[36] M. Hasanah, "Hubungan antara religiusitas dengan resiliensi santri penghafal al Qur'an di pondok pesantren," Proceeding Natl. Conf. Psikol. UMG, vol. 1, no. 1, pp. 84-94, Jul. 2019, [Online]. Available: http://journal.umg.ac.id/index.php/proceeding/article/view/899.

[37] T. R. Andriani and J. Kuncoro, "Hubungan antara Konsep Diri dan Penyesuaian Diri dengan Resiliensi Mahasiswa dalam Menghadapi Banjir dan Rob di UNISSULA," Sultan Agung Fundam. Res. J., vol. 1, no. 1, pp. 69-76, 2020. 